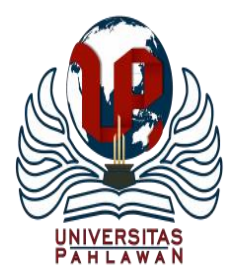

Edukatif : Jurnal Ilmu Pendidikan Volume 3 Nomor 4 Tahun 2021 Halm 1849 - 1858

EDUKATIF: JURNAL ILMU PENDIDIKAN

Research \& Learning in Education

https:/ledukatif.org/index.php/edukatif/index

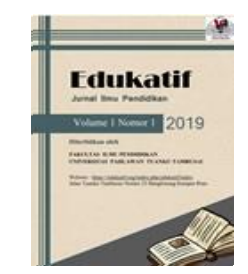

\title{
Analisis Dampak Regulasi Pemerintah Terhadap Moda Belajar Daring Di Rumah Bagi Pelaku Pendidikan Di Madrasah Pada Masa Pandemi Covid-19
}

\author{
Muhammad Suhardi ${ }^{\circledR}$, Ridha Albiy ${ }^{2}$, Nurhizrah Gistituati ${ }^{3}$, Sufyarma Marsidin $^{4}$ \\ Universitas Negeri Padang, Indonesia ${ }^{1,2,3,4}$ \\ E-mail : aji.azella@gmail.com ${ }^{1}$, ridha.albiy.1979@ gmail.com ${ }^{2}$, gistituatinurhizrah@ gmail.com ${ }^{3}$, \\ Sufyarma@ fip.unp.ac.id ${ }^{4}$
}

\begin{abstract}
Abstrak
Dewasa ini fenomena Virus Covid-19 sudah memberikan dampak yang luar biasa pada sektor pendidikan sehingga pemerintah memberikan regulasi tentang moda pembelajaran di masa pandemi. Tujuan penelitian ini ingin menganalisis kebijakan madrasah sebagai institusi pendidikan yang menggunakan moda belajar daring, menggunakan metode penelitian kuantitatif survey yang menggunakan kuesioner untuk mengumpulkan data pokok. Responden berasal dari siswa MI, MTs dan MA dan guru madrasah di wilayah Kota Payakumbuh. Hasil penelitian menunjukkan bahwa moda belajar daring dengan menggunakan kurikulum darurat menimbulkan respon negatif dan positif dari siswa maupun guru terkait dengan penyederhanaan kompetensi dasar, kemampuan guru yang terbatas dan fasilitas penunjang di miliki siswa untuk belajar daring. Penyederhanaan kompetensi dasar menjadi materi esensial dikhawatirkan bisa mereduksi kompetensi siswa, sebagian guru kurang mampu menyampaikan materi secara baik karena kurang menguasai aplikasi dan cenderung hanya memberikan tugas serta keluhan siswa tentang ketiadaan kuota belajar maupun ketiadaan signal di daerah tempat tinggalnya. Moda belajar daring menuntut peningkatan kreatifitas guru dan kontribusi orang tua siswa yang lebih besar pada saat mendampingi siswa belajar.
\end{abstract}

Kata Kunci: Analisis Regulasi, Pembelajaran Daring, Covid 19.

\section{Abstract}

Today the phenomenon of the Covid-19 Virus has had a tremendous impact on the education sector so that the government provides regulations on learning modes during the pandemic. The purpose of this study is to analyze the policies of madrasas as educational institutions that use online learning modes, using a quantitative survey research method that uses a questionnaire to collect basic data. Respondents came from MI, MTs and MA students and madrasa teachers in the Payakumbuh City area. The results showed that the online learning mode using the emergency curriculum caused negative and positive responses from students and teachers related to the simplification of basic competencies, limited teacher abilities and supporting facilities owned by students to learn online. The simplification of basic competencies into essential materials is feared to reduce student competence, some teachers are less able to convey the material properly because they do not master the application and tend to only give assignments and student complaints about the absence of a study quota or the absence of a signal in their area of residence. The online learning mode demands an increase in teacher creativity and a greater contribution from parents when assisting students in learning.

Keywords : Policy Analysis, Online Learning, Covid 19.

Copyright (c) 2021 Muhammad Suhardi, Ridha Alby , Nurhizrah Gistuati, Sufyarma Marsidin

$\triangle$ Corresponding author

Email : aji.azella@gmail.com

DOI : https://doi.org/10.31004/edukatif.v3i4.684

ISSN 2656-8063 (Media Cetak)

ISSN 2656-8071 (Media Online)

Edukatif : Jurnal Ilmu Pendidikan Vol 3 No 4 Tahun 2021 p-ISSN 2656-8063 e-ISSN 2656-8071 
1850 Analisis Dampak Regulasi Pemerintah Terhadap Moda Belajar Daring Di Rumah Bagi Pelaku Pendidikam Di Madrasah Pada Masa Pandemi Covid-19-Muhammad Suhardi, Ridha Alby, Nurhizrah Gistituati, Sufyarma Marsidin

DOI : httphttps://doi.org/10.31004/edukatif.v3i4.684

\section{PENDAHULUAN}

Pendidikan adalah sebuah usaha yang dilakukan oleh individu ataupun kelompok secara sadar dan terencana untuk mewujudkan proses pembelajaran yang efektif dengan tujuan mendidik peserta didik dalam mengembangkan potensi dirinya. Selain itu tujuan pendidikan adalah untuk mengembangkan ilmu pengetahuan dan teknologi serta menjaga warisan budaya dan nilai-nilai. Namun dewasa ini, masih banyak sekali permasalahan-permasalahan di dalam dunia pendidikan yang dapat menghalangi tercapainya tujuantujuan yang diharapkan.

Permasalahan di dalam pendidikan tersebut merupakan prioritas utama yang harus dipecahkan, sesuai dengan amanah konstitusi negara kita yaitu UUD 1945 yang menegaskan bahwa salah satu tujuan pendidikan adalah mencerdaskan kehidupan bangsa. Sehingga seluruh unsur dan warga indonesia adalah memiliki tugas dan peranan yang sama yaitu sebagai agen dan komponen pendidikan itu sendiri.

Dewasa ini, ada fenomena yang mendunia yaitu sebuah pandemi yang bersifat global dan memberikan dampak kepada seluruh lini kehidupan termasuk pendidikan di negara kita. Kondisi pendidikan saat ini tengah mengalami tantangan sebagai dampak mewabahnya virus Covid-19. Corona virus disease 2019 (Covid-19) menjelma sebagai pandemik global yang menurut WHO memiliki penyebaran yang begitu membuat dunia khawatir. Akibatnya seluruh lini seperti politik, terlebih lagi ekonomi, sosial, budaya, pertahanan, pendidikan, dan kesehatan masyarakat terkena dampaknya (Adha et al., 2020) sehingga pemerintah harus bekerja sama untuk menekan laju penyebaran virus Covid-19 dengan mengeluarkan kebijakan agar seluruh warga masyarakat untuk melakukan social distancing atau menjaga jarak (Yunitasari \& Hanifah, 2020). Sehingga dengan adanya kebijakan tersebut seluruh aktivitas masyarakat yang dulu dilakukan di luar rumah dengan berkumpul dan berkelompok, kini harus diberhentikan sejenak dan diganti dengan beraktivitas di rumah masing-masing.

Penyebaran virus corona ini pada awalnya sangat berdampak bagi dunia ekonomi yang sangat memukul dunia usaha mulai dari perusahaan yang bersekala besar seperti ditutupnya sebuah grup Giant sampai tingkat UMKM seperti para pedagang di pasar maupun pedagang kaki lima, dan akhirnya kini berdampak kepada dunia pendidikan. Kebijakan yang sudah diambil oleh banyak negara dan termasuk Indonesia juga dengan meliburkan seluruh aktivitas pendidikan, dan membuat pemerintah dan lembaga terkait harus menghadirkan alternatif untuk proses pendidikan bagi peserta didik maupun mahasiswa yang sekarang tidak bisa melaksanakan proses pembelajaran atau proses pendidikan pada suatu lembaga pendidikan (Aji et al., 2020).

Adanya virus COVID-19 pada tahun 2020 memberikan dampak yang luar biasa hampir pada semua bidang, salah satunya pada bidang pendidikan (Moralista \& Oducado, 2020). Pendidikan yang dikelola oleh madrasah yang berada di bawah kementerian agama pun termasuk yang terkena dampaknya, banyak madrasah yang melakukan pembelajaran dari rumah (BDR) sebagai akibat dari merebaknya virus yang mematikan ini.

Kementerian Agama telah menerbitkan Surat Edaran (SE) nomor 3 tahun 2020 yang mengatur tentang pencegahan penyebaran virus Covid-19 ini dengan memberlakukan social distancing dan bekerja dari rumah (WFH) agar terhindar dari kerumunan (Studi et al., n.d.) termasuk madrasah dilarang melakukan pembelajaran tatap muka atau pembelajaran dilakukan dari rumah, Surat Edaran ini kemudian dirubah lagi dengan Nomor 4, 5, 6 dan 7 masih dengan pencegahan penyebaran virus Covid-19. Kemudian menteri agama juga memberikan regulasi tentang kurikulum darurat melalui Kepdirjen Pendis No 2791 Tahun 2020 sehingga seluruh madrasah praktis melakukan proses belajar mengajar tidak hanya memenuhi kompetensi KI dan KD namun lebih menekankan kepada pengembangan karakter, kemandirian dan ubudiyah siswa sementara alokasi waktu jam pelajaran justru dikurangi dan juga memfokuskan kepada pelakasanaan proses belajar mengajar dilakukan dari rumah menggunakan sistem dalam jaringan (daring) yaitu pembelajaran secara virtual atau non tatap muka 
1851 Analisis Dampak Regulasi Pemerintah Terhadap Moda Belajar Daring Di Rumah Bagi Pelaku Pendidikam Di Madrasah Pada Masa Pandemi Covid-19-Muhammad Suhardi, Ridha Alby, Nurhizrah Gistituati,

Sufyarma Marsidin

DOI : httphttps://doi.org/10.31004/edukatif.v3i4.684

tergantung kepada kebijakan kepala daerah setempat, yang setiap waktu bisa berubah-ubah sesuai status zona covid-19.

Di alam pelaksanaan pembelajaran daring kementerian agama juga merujuk kepada siaran pers Kemendikbud dengan nomor 719/P/2020 pada Jumat (07/08) tentang Pedoman Pelaksanaan Kurikulum pada Satuan Pendidikan dalam Kondisi Khusus. Kurikulum darurat disebut menjadi alternatif penyederhanaan kompetensi dasar yang tetap mengacu pada Kurikulum 2013. Bedanya, kurikulum ini diberikan pengurangan kompetensi dasar dari seluruh mata pelajaran yang ada, sehingga kurikulum ini hanya fokus pada bagian kompetensi esensial dan prasyarat untuk menyiapkan persiapan pembelajaran ke tingkat selanjutnya.

Pembelajaran daring memerlukan berbagai sarana pendukung seperti smartphone, komputer atau laptop, sinyal yang kuat dan stabil serta berbagai aplikasi yang mendukung yang tertanam (terinstall) pada smartphone yang memungkinkan tercapainya tujuan pembelajaran (Darmalaksana, 2020). Umumnya guru memberikan materi dan tugas kepada siswa melalui aplikasi whatsapp dan juga video yang diunggah di youtube (Johnes \& Johnes, 2004). Namun hal ini tidak semudah yang dibayangkan karena tidak semua daerah terjangkau signal telepon seluler, dan tidak semua mempunyai keterampilan yang memadai untuk mengelola pembelajaran daring sehingga menimbulkan interaksi yang kurang maksimal dan terarah dengan baik (Adib Rifqi Setiawan, 2020).

Kebijakan pembelajaran daring mengakibatkan gangguan psikilogis dan bisa menurunkan kualitas keterampilan siswa (Adha et al., 2020), gangguan juga terjadi pada komunikasi guru dan siswa, karena komunikasi cenderung satu arah dan menunggu respon dari siswa terlebih dahulu, sehingga siswa merasa kurang bisa menyerap penjelasan dari guru apalagi terkadang terjadi gangguan sinyal yang hilang-hilang timbul. (KPAI, 2020) juga mendapat sejumlah laporan dari siswa dan masyarakat problematikan pembelajaran daring, lalu KPAI membuat penelitian yang menghasilkan data bahwa didapati (77\%) siswa yang cenderung merasa berat dengan banyaknya tugas yang diberikan oleh guru, laporan yang lain adalah kuota yang tidak dimiliki secara memadai (42\%). Berdasarkan kondisi inilah maka perlu adanya analisis dampak regulasi pemerintah tentang belajar daring.

\section{METODE PENELITIAN}

Jenis metode penelitian yang digunakan dalam penelitian ini adalah jenis penelitian survey research. Metode penelitian survey atau secara ringkas biasa disebut metode survey adalah penelitian yang sumber data dan informasi utamanya diperoleh dari responden sebagai sampel penelitian dengan menggunakan kuesioner atau angket sebagai instrumen pengumpulan data.

Pada umumnya, sampel yang digunakan sebagai unit analisis adalah individu. Namun demikian, unit lain seperti rumah tangga, kelompok, perusahaan, sampai negara bisa pula digunakan sebagai unit analisis. Salah satu yang perlu diingat dalam penelitian survey adalah penggunaan sampel sebagai sumber data primer.

Teknik pengumpulan data dalam penelitian ini adalah melalui penyebaran angket menggunakan lembar kuesioner melalui aplikasi google form dan hasil penelitian cenderung untuk di-generalisasikan (Sugiyono, 2015). Sampel dalam penelitian ini adalah 244 pelaku pendidikan yang teridiri dari 58 guru, dan 186 siswa di kota Payakumbuh Sumatera Barat. Teknik analisis data yang digunakan dalam penelitian ini adalah dengan teknik analisis deskriptif. Analisis deskriptif adalah statistik yang digunakan untuk menganalisis data dengan cara mendeskripsikan atau menggambarkan data yang telah terkumpul sebagaimana adanya tanpa bermaksud membuat kesimpulan yang berlaku untuk umum atau generalisasi. 
1852 Analisis Dampak Regulasi Pemerintah Terhadap Moda Belajar Daring Di Rumah Bagi Pelaku Pendidikam Di Madrasah Pada Masa Pandemi Covid-19-Muhammad Suhardi, Ridha Alby, Nurhizrah Gistituati,

Sufyarma Marsidin

DOI : :httphttps://doi.org/10.31004/edukatif.v3i4.684

\section{HASIL DAN PEMBAHASAN PENELITIAN}

Pada masa Pandemi Covid-19 pemerintah melalui kementerian agama membuat kebijakan yang khusus dilaksanakan di madrasah yang meruapakan lembaga pendidikan yang berada di bawah kementerian agama. Di mulai dari RA, MI, MTs dan MA smpai kepada perguruan tinggi Islam, di kota Payakumbuh seluruh madrasah melakukan proses belajar mengajar dengan sistem daring yaitu pembelajaran dengan menggunakan platform virtual seperti zoom, google meet atau teleconference dan komunikasi whatsapp, google classroom ataupun google formulir untuk beberapa ujian dan luar jaringan (luring), sistem yang terakhir ini ditempuh karena memang tidak memungkinkan dilakukan pembelajaran daring dikarenakan berbagai hal, yaitu ketiadaan signak maupun ketersediaan laptop, maupun gawai untuk pembelajaran daring, setiap madrasah memiliki karakteristik tersendiri terkait dengan demografi dan topografinya, demografi yaitu siswa yang memiliki tempat tinggal yang jauh di kabupaten namun bersekolah dan tinggal di kost di kota, dan pada saat diberlakukan pembelajaran daring, maka siswa tersebut akan pulang kampung dan belajar daring di rumah, dan masalah pun timbul yaitu daerah tempat tinggalnya tidak terjangkau oleh signal.

Sistem luring diambil sebagai alternatif pemecahan masalah signal, yaitu siswa akan datang secara bergantian dengan menggunakan protokol kesehatan yang ketat, untuk mengambil tugas ke madrasah di awal minggu dan akan mengerjakan di rumah dan kembali akan mengantarkan tugas selama seminggu kemudian menyerahkan tugas di awal minggu berikutnya seraya mengambil tugas untuk seminggu ke depannya.

Kebijakan pembelajaran daring dan luring menimbulkan permasalahan baik dari sisi guru maupun siswa yaitu tugas menumpuk untuk dikerjakan, jaringan atau signal yang terkadang tidak bersahabat, dan dana untuk membeli pulsa atau kuota internet. Kendala dan masalah yang dialami oleh pendidik selama pembelajaran dari rumah yaitu menyusun kegiatan pembelajaran yang kreatif dan inovatif agar siswa dapat mencapai target pengetahuan, keterampilan, dan sikap yang dibangun dalam proses belajarnya. (Bilfaqih \& Qomarudin, 2015).

(KPAI, 2020) mengungkapkan data bahwa siswa mengalami kesulitan pembelajaran secara daring yaitu $77 \%$ menyatakan keluhan tugas yang menumpuk, 42,20\% mengeluhkan tidak mempunyai kuota internet, $37,10 \%$ waktu belajar yang tidak mencukupi, dan 15, $60 \%$ tidak mempunyai perangkat pendukung pembelajaran daring yaitu smartphone, dan laptop. Fenomena ini bukan saja menyisakan banyak kegelisahan di masyarakat tetapi juga kendala yang cukup memusingkan para guru, karena guru tidak bisa memantau siswa belajar secara optimal. Hal ini sesuai dengan hasil penelitian yang dilakukan oleh KPAI yang menyatakan bahwa $73,20 \%$ siswa merasa berat dan $26,80 \%$ merasa tidak berat, sehingga guru hatrus lebih kreatif dan inovatif.

\section{Dampak bagi guru}

Berdasarkan hasil penelitian melalui angket menggunakan fasilitas google form yang disebarkan kepada guru pada tanggal 28 Maret 2021. Responden yang telah mengisi angket berjumlah 58 guru yaitu 6 guru MI, 26 guru MTS, dan 26 guru MA se kota Payakumbuh. Hasil angket menyatakan bahwa 15,3\% sangat setuju dan 38,4\% setuju terkait pembatasan sosial dan kerja di rumah akibat pandemi Covid-19 (Gambar 1) karena itu adalah kebijakan pemerintah melalui perwako Payakumbuh. Namun kebijakan tersebut membuat guru tidak mampu mencapai target materi yang telah disusun dalam Program Semester (Promes). Program Semester yang berfungsi untuk mengetahui beban materi dalam satu semester. Penerapan pembelajaran dalam jaringan (daring) mengakibatkan proses pembelajaran terhambat karena beberapa guru senior tidak mampu mengaplikasikan internet atau gagap teknologi. Maka perlu adanya pendampingan dan pelatihan pembelajaran melalui dalam jaringan (daring). Selama pandemi Covid-19 proses pembelajaran berlangsung secara searah, sehingga siswa dan guru dapat menggunakan fasilitas paltform e-learning seperti Ruang Guru, Google Clasroom, Google Meet, dan Zoom. Pembelajaran dalam jaringan (daring) di tengah pandemi Covid-19 hendaknya mampu memfasilitasi pengalaman belajar siswa, namun pembelajaran dalam jaringan (daring) saat ini guru hanya memberikan tugas kepada siswa untuk dikerjakan. Berdasarkan survei KPAI (2020) terdapat 
1853 Analisis Dampak Regulasi Pemerintah Terhadap Moda Belajar Daring Di Rumah Bagi Pelaku Pendidikam Di Madrasah Pada Masa Pandemi Covid-19-Muhammad Suhardi, Ridha Alby, Nurhizrah Gistituati,

Sufyarma Marsidin

DOI : httphttps://doi.org/10.31004/edukatif.v3i4.684

76,6\% siswa tidak senang dengan pembelajaran dalam jaringan (daring) di rumah. Kesulitan belajar siswa berasal dari tugas yang menumpuk dan tidak memiliki kuota internet. Hal ini sesuai dengan pernyataan dari bapak Joni Akmal usia 54 Tahun seorang guru MI menyatakan bahwa pembelajaran dalam jaringan (daring) dilakukan dengan memberikan tugas melalui grup whatsapp wali murid yang bertujuan untuk memberikan aktivitas siswa di rumah. Pemberian tugas yang menumpuk dapat diganti dengan pembuatan karya berupa lagu, puisi, essay, dan karya tulis mengenai Covid-19. Berdasarkan kompas.com menyatakan bahwa pembelajaran dalam jaringan (daring) dapat dilakukan dengan memberikan ilmu mengenai penyebaran Covid19 misalnya gejala yang timbul akibat Covid-19, isolasi mandiri selama 14 hari, sehingga kegiatan tersebut mampu menekan penyebaran Covid-19 dan meningkatkan kepedulian sosial.

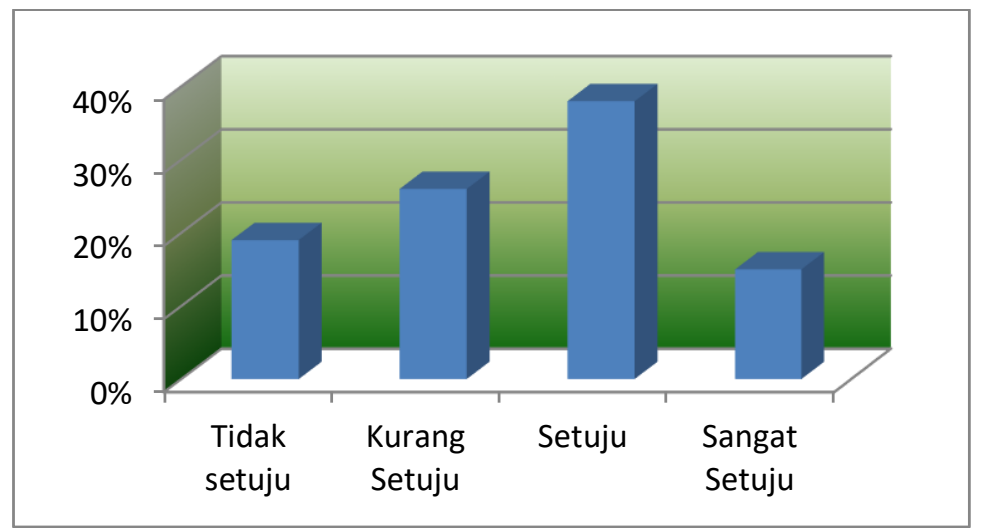

Gambar 1. Kebijakan belajar dari rumah menurut guru

Berdasarkan angket tentang pertanyaan terkait dengan penyederhanaan kurikulum yaitu pengurangan materi yang tercantum pada Kompetensi Inti (KI) dan Kompetensi Dasar (KD) terdapat hasil penelitian yang menyatakan bahwa $34 \%$ guru menyatakan setuju dengan penyederhanaan kurikulum, namun yang menarik adalah terdapat sebanyak $30 \%$ guru yang menyatakan tidak setuju dan $23 \%$ yang kurang setuju dengan penyederhanaan kurikulum (gambar 2). Hal ini dikuatkan dengan pernyataan Ibu Aisyah usia 54 tahun yang tidak setuju dengan penyederhanaan kurikulum karena menurut beliau bisa mengurangi kemampuan yang akan dicapai oleh siswa, dan dikhwatirkan akan berefek kepada mutu lulusan madrasah, juga dikuatkan dengan pernyataan Ibu Dona Yusri usia 48 tahun yang khawatir jika kompetensi inti dan kompetensi dasar disederhanakan menjadi materi esensial maka dikhawatirkan siswa tidak bisa menjawab soal ujian akhir dan tidak bisa pula menjawab soal-soal pada seleksi jenjang sekolah yang lebih tinggi karena jumlah kompetensi dasar yang dikurangi berkisar dari 45 sampai 75 persen (Indriani, 2020). Adapun guru yang menyatakan setuju dengan penyederhanan kompetensi dasar karena ini adalah kebijakan pemerintah yang harus dilaksanakan.

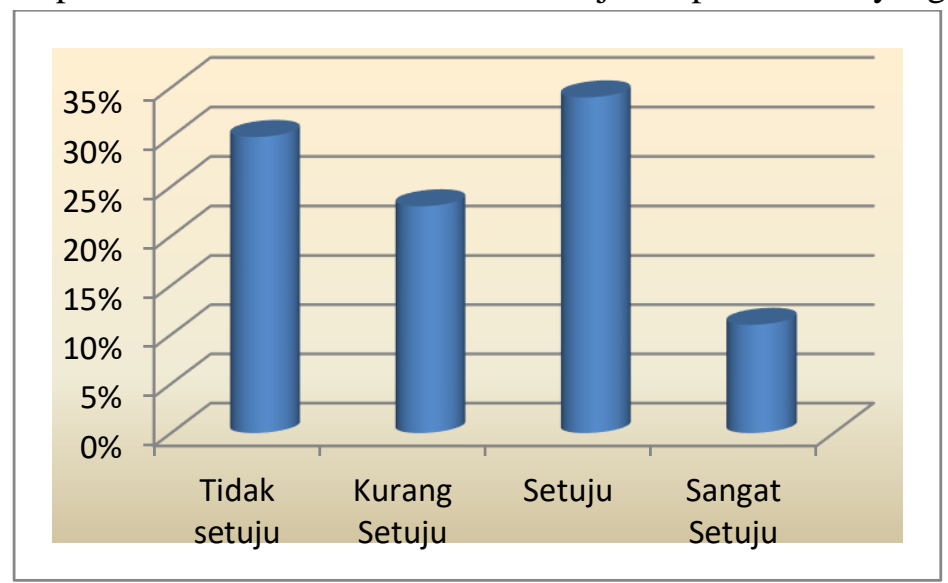

Gambar 2. Hasil angket Penyederhanaan kompetensi dasar bagi guru 
1854 Analisis Dampak Regulasi Pemerintah Terhadap Moda Belajar Daring Di Rumah Bagi Pelaku Pendidikam Di Madrasah Pada Masa Pandemi Covid-19-Muhammad Suhardi, Ridha Alby, Nurhizrah Gistituati, Sufyarma Marsidin

DOI : httphttps://doi.org/10.31004/edukatif.v3i4.684

Berdasarkan angket pada pertanyaan terkait pembelajaran berbasis pengembangan karakter, akhlak mulia dan kemandirian siswa (contectual learning), melalui pembelajaran dalam jaringan (daring) hasil penelitian menyatakan $30,7 \%$ setuju (Gambar 3). Hal ini disebabkan pembelajaran berbasis kehidupan bertujuan untuk mengarahkan siswa untuk menjadi pribadi yang utuh, sehingga mampu memecahkan masalah dan menjalani kehidupan secara berimbang. Menariknya, terdapat 38,46 \% yang mengatakan tidak setuju karena pembelajaran pengembangan karakter kurang bisa diserap oleh siswa jika melalui daring karena siswa akan hanya mendapatkan komunikasi yang searah dan guru akan cenderung mendapatkan feedback yang tidak langsung atau terjeda. Pembelajaran juga berbasis akhlak mulia dan ubudiyah juga tidak akan maksimal dikarenakan tidak semua guru memiliki latar belakang keagamaan dan akidah, sebagaimana yang dinyatakan oleh bapak Fitdiyahwati usia 46 tahun seorang guru bahasa indonesia yang merasa kurang mampu memberikan pembelajaran ubudiyah kepada siswanya karena beliau adalah berlatar belakang pendidikan umum. Hal ini menjadi penting karena guru yang tidak memiliki latar belakang pendidikan yang sesuai bidangnya maka guru tidak tersbut tidak akan bisa mengajar secara profesional dan maksimal (Ondi, 2010). Pembelajaran berbasis kehidupan paling banyak dilaksanakan di jenjang pendidikan Sekolah Dasar dan sederajat seperti Madrasah Ibtidaiyah sehingga guru SD/MI harus mampu mengaitkan pembelajaran dengan kehidupan sehari-hari. Selama pandemi Covid-19 pembelajaran berbasis kehidupan (contectual learning) dapat dilaksanakan melalui ilustrasi pencegahan Covid-19 dengan memberikan tontonan video edukasi. Pembelajaran berbasis kehidupan juga dapat dilakukan dengan memberikan permasalahan di kehidupan nyata.

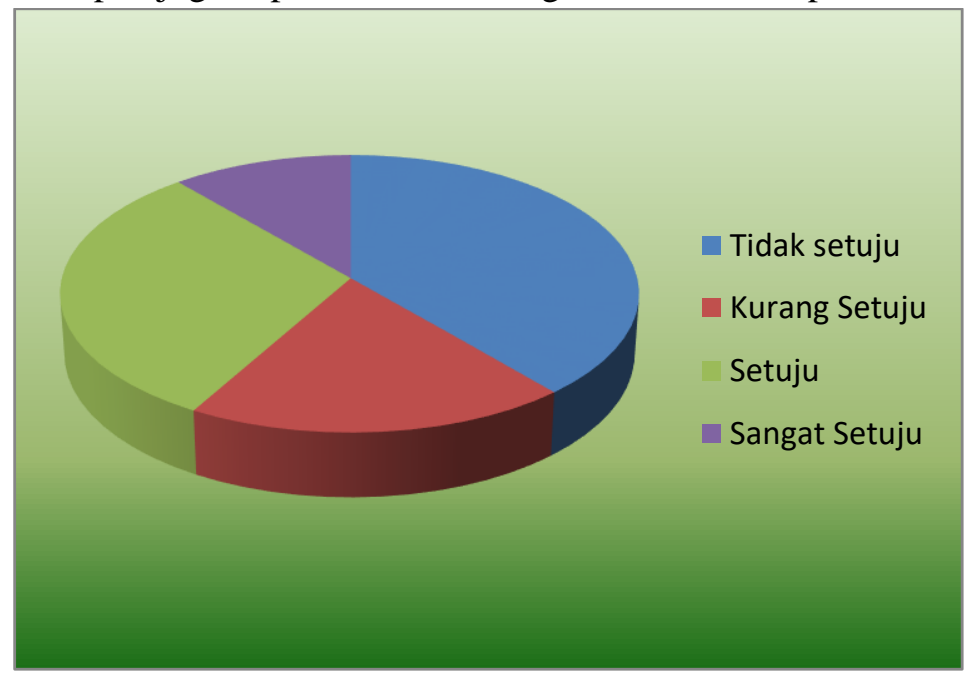

Gambar 3. Hasil angket pelaksanaan pembelajaran karakter, ubudiayah dan kemandirian

Berdasarkan angket pada pertanyaan apakah pembelajaran dalam jaringan (daring) memberikan kemudahan kepada Bapak/Ibu dalam menyampaikan materi hasil menyatakan bahwa 23,07\% kurang mampu dan 50,\% mampu pembelajaran dilakukan secara dalam jaringan (daring) (Gambar 4). Hal ini diakibatkan beberapa guru merasa kesulitan dalam menyampaikan muatan kurikulum pembelajaran kepada siswa seperti yang dinyatakan oleh Ibu Rinawati usia 51 Tahun mengajar MA menyatakan bahwa pembelajaran dalam jaringan (daring) memberikan kesulitan dalam menjelaskan materi matematika, sehingga Ibu Rinawati melakukan shooting video pembelajaran kemudian dishare kepada siswa melalui aplikasi whatsapp. Namun hal ini tidak sejalan dengan apa yang dinyatakan oleh Ibu Verawati usia 44 tahun dan Bapak Jefrinaldi usia 27 tahun yang masing masing mengajar mata pelajaran bahasa inggris dan bahasa arab di tingkat madrasah aliyah merasa nyaman dan mampu menyampaikan materi dengan menggunakan moda daring karena kebetulan guru ini menguasai keterampilan dan beberapa aplikasi di komputer untuk mengolah dan menyampaikan melalui 
smartphone kepada siswa. Maka perlu adanya alternatif yang dilakukan oleh pemerintah untuk memberikan fasilitas aplikasi bagi guru matematika, fisika, dan kimia yang membutuhkan penjelasan mengenai penerapan rumus. Berdasarkan cnn.com proses pembelajaran pada mata pelajaran berhitung dapat dilakukan melalui powerpoint dan google meet tetapi kendalanya tidak semua siswa mampu mengakses karena tidak memiliki handphone dan orang tua yang gagap teknologi. Adapun angka $15 \%$ menyatakan sangat mampu umumnya mereka adalah guru baru yang baru saja tamat kuliah pendidikan guru sehingga masih sangat up to date.

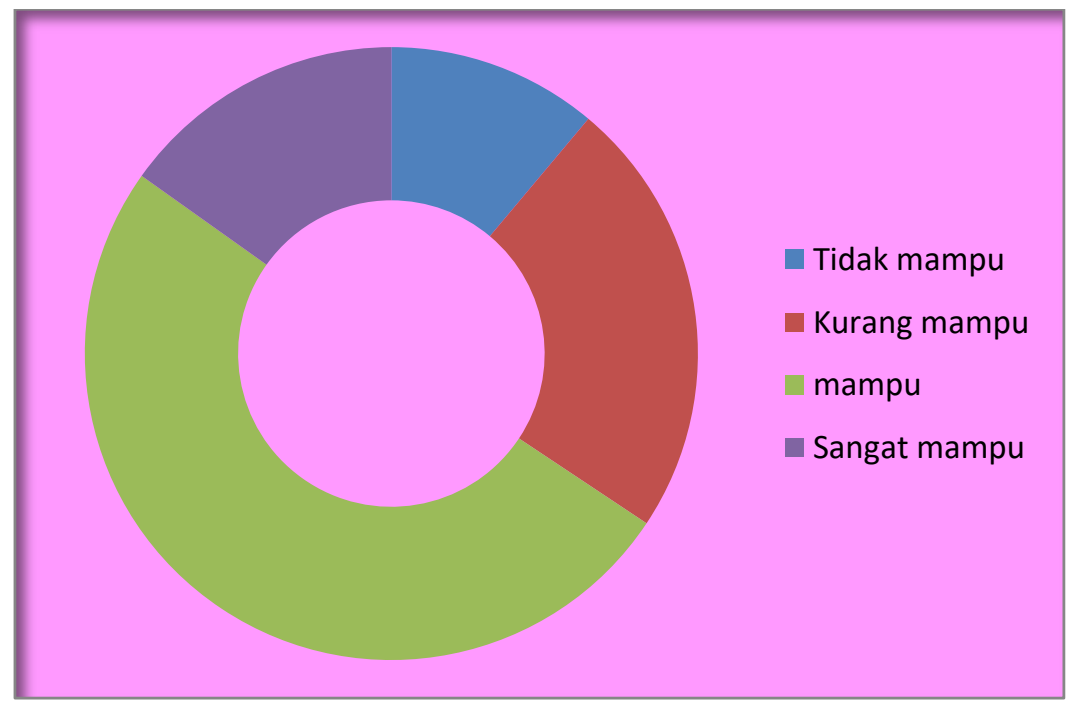

Gambar 4. Angket kemampuan guru dalam melaksanakan pembelajaran secara daring

\section{Dampak bagi Siswa}

Berdasarkan hasil penelitian melalui angket menggunakan fasilitas google form yang disebarkan kepada siswa pada tanggal 28 Maret 2021. Responden yang telah mengisi angket berjumlah 134 siswa yaitu 12 siswa MI, 64 siswa MTS, dan 58 siswa MA. Hasil angket menyatakan bahwa 37,3\% setuju dan 22,3\% kurang setuju (Gambar 6) terkait anjuran pemerintah mengenai pembatasan sosial dan kerja di rumah aja. Pandemi Covid-19 memaksa pelaksanaan belajar mengajar dilakukan secara online atau dalam jaringan (daring), sehingga siswa melakukan aktivitas belajar menggunakan fasilitas smartphone dan laptop. Pembelajaran dalam jaringan (daring) mengakibatkan siswa harus melakukan pendalaman materi secara otodidak, hal ini disebabkan karena guru tidak leluasa memberikan pengawasan secara langsung. Muhammad Zaki seorang pelajar MA menyatakan bahwa pembelajaran dalam jaringan (daring) menghambat proses mengingat materi karena pembelajaran berlangsung hanya sekedar chatting, dan beberapa guru memberikan materi yang hanya berupa potongan-potongan penjelasan yang terbatas. Hal ini tentu saja menyebabkan siswa hanya menulis dan mengingat materi tanpa memahami maksud dari materi tersebut (Agestiyani, 2020). Siswa memiliki karakteristik belajar yang unik dan berbeda, sehingga guru harus memiliki keterampilan menjelaskan agar mampu memfasilitasi pengetahuan siswa. 


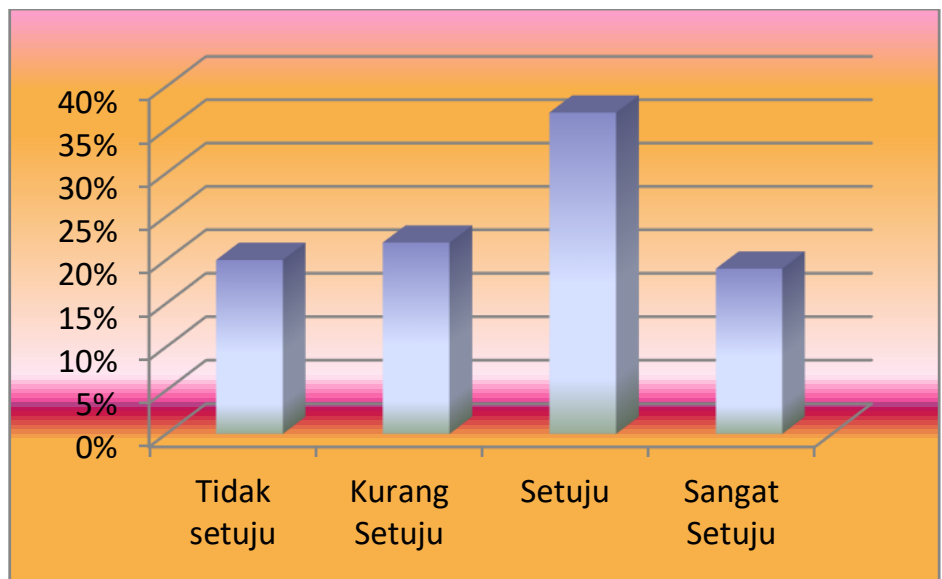

Gambar 5. Hasil angket pembelajaran daring bagi siswa

Berdasarkan angket pada pertanyaan kepada siswa apakah adik-adik merasa nyaman dan berhasil dengan proses pembelajaran dalam jaringan (daring) hasil menyatakan bahwa 38,8\% kurang setuju dan 25,3\% tidak setuju (Gambar 6). Pembelajaran dalam jaringan (daring) selama pandemi Covid-19 hanya berlangsung satu arah. Guru hanya memberikan penjelasan yang sedikit sehingga siswa belum menyerap substansi materi yang disampaikan dan malah justru tugas yang banyak diberikan melalui aplikasi whatsapp dengan memberikan rentang waktu pengerjaan. Hal ini bertentangan dengan karakteristik pembelajaran kurikulum 2013 revisi yang menyatakan bahwa pembelajaran harus berlangsung secara dua arah dan multiarah. Ayu seorang pelajar MA menyatakan bahwa mereka enggan dan kurang bersemangat mengerjakan tugas, karena banyak materi yang belum jelas tapi justru disuruh mengerjakan soal dan tugas sehingga mereka merasa frustasi (Jatira \& S, 2021) dan justru mencari selingan yang lebih menarik yaitu bermain media sosial. Belajar daring memberikan konsekuensi intensitas yang tinggi dengan penggunaan smartphone dan laptop, sehingga akan menimbulkan efek samping kecanduan dalam memegang gadget. Maka keterampilan guru dalam merencanakan pembelajaran haruslah sebaik mungkin agar mencapai tujuan pembelajaran dengan memanfaatkan jaringan komputer dan internet dengan tepat sasaran dan peran orang tua penting sebagai pendamping siswa semasa pembelajaran dalam jaringan (daring).

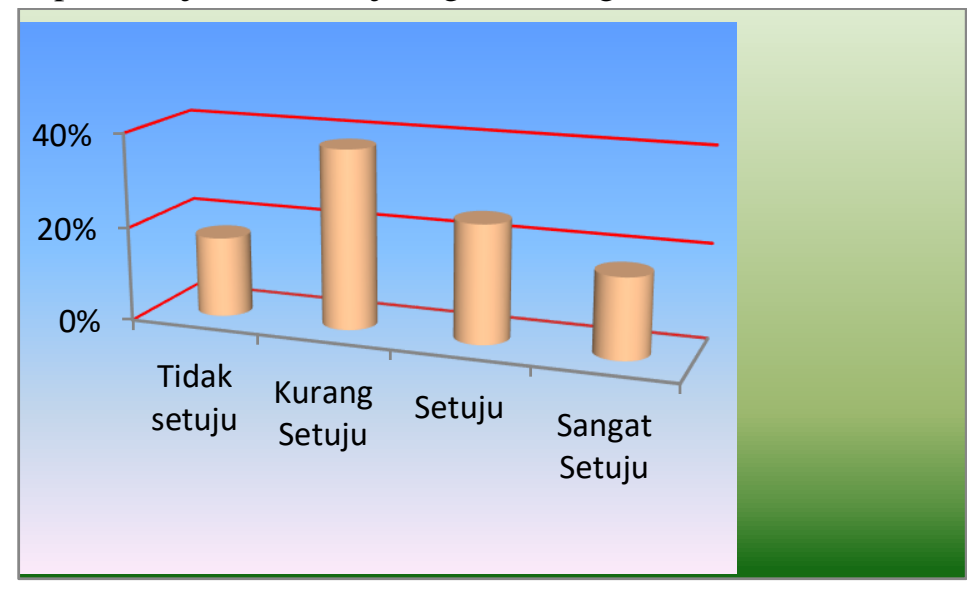

Gambar 6. Efektifitas pembelajaran daring bagi siswa

Berdasarkan hasil penelitian melalui angket tentang fasilitas dan aplikasi serta jaringan yang mendukung proses belajar daring. Hasil angket menyatakan bahwa 43,2\% setuju dan 25,3\% kurang setuju (Gambar 6) terkait fasilitas yang dimiliki oleh siswa banyak yang tidak mendukung atau kompatible terhadap tugas yang diharapkan, hal ini dapat kita maklumi bahwa pandemi Covid 19 sangat memukul roda 
1857 Analisis Dampak Regulasi Pemerintah Terhadap Moda Belajar Daring Di Rumah Bagi Pelaku Pendidikam Di Madrasah Pada Masa Pandemi Covid-19-Muhammad Suhardi, Ridha Alby, Nurhizrah Gistituati,

Sufyarma Marsidin

DOI : httphttps://doi.org/10.31004/edukatif.v3i4.684

perkekonomian masyarakat (Wuryandani, 2020) sehingga sangat menjadi beban bagi masyarakat untuk membeli smartphone dengan kecanggihan yang tinggi. Hal senada juga diungkapkan oleh Ikhsan siswa MTs yang mengatakan bahwa bukan saja handphone yang tidak kompatible, kuota yang diberikan pemerintah melalui beberapa provider justru tidak terpakai, karena guru hanya menggunakan aplikasi whatsapp dan bukan aplikasi platform yang canggih, ada pula Indah siswa MA yang mengatakan ada provider lain yang memberikan banyak kuota namun signal provider itu tidak bisa tertangkap di daerah tempat tinggalnyan dan harus pergi ke tempat yang tinggi untuk menggapai sinyalnya karena pelajar di kota payakumbuh banyak yang berasal dari luar kota Payakumbuh. Pandemi Covid-19 memaksa pelaksanaan belajar mengajar dilakukan secara online atau dalam jaringan (daring), sehingga siswa melakukan aktivitas belajar menggunakan fasilitas smartphone dan laptop.



Gambar 7. Fasilitas dan kualitas signal pembelajaran daring bagi siswa

\section{KESIMPULAN}

Berdasarkan hasil penelitian yang sudah dilakukan, dapat diambil kesimpulan bahwa para pelaku pendidikan juga terkena dampak kasus pandemi Virus Covid-19, para pelaku pendidikan baik guru maupun siswa diwajibkan belajar dan mengajar serta bekerja dari rumah sesuai dengan perintah dan regulasi dari pemerintah yang mengatur hal itu. Pembelajaran dilakukan dengan moda daring dengan menggunakan sistem online, dengan menjalankan pengurangan kompetensi dasar dan menggunakan kurikulum darurat. Kegiatan itu direspon postif maupun negatif oleh pihak guru dan juga siswa terkait dengan minimnya fasilitas yang menunjang proses belajar mengajar secara daring. Belajar daring memberikan dampak positif terhadap pencegahan penyebaran virus corona namun berdampak negatif bagi proses pendidikan yaitu proses belajar mengajar yang kurang efektif bagi sebagian guru dan siswa di madrasah di Kota Payakumbuh.

\section{DAFTAR PUSTAKA}

Adha, M. A., Arifin, I., Maisyaroh, M., Sultoni, S., \& Sunarni, S. (2020). Analisis Dampak Anjuran Pemerintah Terhadap Belajar Di Rumah Bagi Pelaku Pendidikan. Jurnal Administrasi Dan Manajemen Pendidikan, 3(3), 216-223. https://doi.org/10.17977/um027v3i32020p216

Adib Rifqi Setiawan. (2020). Tanggapan Grace Natalie terhadap COVID-19. Edukatif: Jurnal Ilmu Pendidikan, 2(1), 28-37.

Agestiyani, L. (2020). Pemahaman konsep keragaman budaya Indonesia melalui auditory, intellectually , repetition ( AIR ) learning model pada peserta didik kelas IV sekolah dasar. Jurnal Didaktika Dwija Indria, 8, 1-5. 
1858 Analisis Dampak Regulasi Pemerintah Terhadap Moda Belajar Daring Di Rumah Bagi Pelaku Pendidikam Di Madrasah Pada Masa Pandemi Covid-19-Muhammad Suhardi, Ridha Alby, Nurhizrah Gistituati,

Sufyarma Marsidin

DOI : :httphttps://doi.org/10.31004/edukatif.v3i4.684

Aji, W., Dewi, F., Kristen, U., \& Wacana, S. (2020). DAMPAK COVID-19 TERHADAP IMPLEMENTASI PEMBELAJARAN DARING DI. 2(1), 55-61.

Bilfaqih \& Qomarudin. (2015). Esensi Pengembangan Pembelajaran Daring. Deepublish.

Darmalaksana, W. (2020). WhatsApp Kuliah Mobile. 1-7.

Indriani. (2020). JUmlah Kompetensi Dasar dikurangi. https://www.antaranews.com/berita/1700174/jumlahkompetensi-dasar-pada-kurikulum-darurat-dikurangi

Jatira, Y., \& S, N. (2021). Fenomena Stress dan Pembiasaan Belajar Daring dimasa Pandemi Covid-19. Edukatif: Jurnal Ilmu Pendidikan, 3(1), 35-43. https://doi.org/10.31004/edukatif.v3i1.187

Johnes, G., \& Johnes, J. (2004). International Handbook on the Economics of Education (Issue January). https://doi.org/10.4337/9781845421694

KPAI. (2020). Guru Tak Boleh Bebankan Tugas di Luar Kemampuan Siswa. https: //news.detik.c om/berita/d4993866/kemendikbud-guru-tak-boleh-bebankan-tugas-diluar-kemampuansiswa?_ga=2.57169258.1117432155.1589810068-177998992.1488448910

Moralista, R. B., \& Oducado, R. M. F. (2020). Faculty Perception toward Online Education in a State College in the Philippines during the Coronavirus Disease 19 ( COVID-19) Pandemic. 8(10), 4736-4742. https://doi.org/10.13189/ujer.2020.081044

Ondi, S. (2010). Etika Profesi Keguruan. Refika Aditama.

Studi, P., Pendidikan, T., Kurikulum, J., Teknologi, D. A. N., Pendidikan, F. I., \& Semarang, U. N. (n.d.). ONLINE DI SMK NU UNGARAN.

Sugiyono. (2015). Metode Penelitian Pendidikan Pendekatan Kuantitatif, Kualitatif, Dan R\&D (1st ed.). CV. Alfabeta.

Wuryandani, D. (2020). potensi Pertumbuhan Ekonomi Semester 3/2020. Info Singkat Bidang Ekonomi Dan Kebijakan Publik Pusat Penelitian Badan Keahlian DPR RI, 21-24.

Yunitasari, R., \& Hanifah, U. (2020). Pengaruh Pembelajaran Daring terhadap Minat Belajar Siswa pada Masa COVID 19. Edukatif: Jurnal Ilmu Pendidikan, 2(3), 232-243. https://doi.org/10.31004/edukatif.v2i3.142 